\title{
Co-evolution and Contradiction: A Diamond Model of Designer-User Interaction
}

\author{
Anja-Karina Pahl and Linda B. Newnes \\ University of Bath, Claverton Down, UK
}

\section{A.K.Pahl@bath.ac.uk L.B.Newnes@bath.ac.uk}

\begin{abstract}
This paper explores how the engineering design process might balance conflicting constraints of technical product design and the social demands of users. Some insights from Buddhism, cybernetics, phenomenology and neurophysiology set the scene to help illustrate how Designers and Users build or access their respective 'experienced-` and 'expected world' and achieve their aims. A prototype 3D 'diamond model' is presented, which expands on previous work by the authors of this paper and is compared with Beer's [1994] Team Syntegrity protocol, to structure conversations and activities between two groups with apparently opposing aims. This provides a necessary common purpose and worldview, through which conversations and activities can become innovative, mutually informing, co-evolving and emotionally satisfactory at both the individual and team levels.
\end{abstract}

Keywords: Innovation, co-evolution, non-dualism, Buddhism, phenomenology, cybernetics, VSM, Team Syntegrity

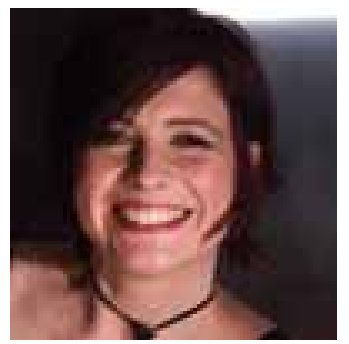

\section{Biographies}

Anja-Karina Pahl is currently a Research Officer and staff $\mathrm{PhD}$ candidate in the IMRC of the Department of Mechanical Engineering at the University of Bath. From a back-ground in Structural Geology, she trained in TRIZ methods in 2000 and developed a short course for the Swinburne School of Management MBA and Executive Develop-ment Programme in Innovation and Entrepreneurship in Melbourne before moving to the University of Bath. Her previous 3-year contract involved knowledge transfer be-tween Biology and Engineering. During this time she was also responsible for setting up the MSc in Biomimetic and Technical Creativity. Her current research concentrates on the development of a new synthesis of commercial and nonwestern methods for creativity and innovation. The test-bed is a part of a full-industry-funded

Material published as part of this publication, either on-line or in print, is copyrighted by the Informing Science Institute. Permission to make digital or paper copy of part or all of these works for personal or classroom use is granted without fee provided that the copies are not made or distributed for profit or commercial advantage AND that copies 1) bear this notice in full and 2) give the full citation on the first page. It is permissible to abstract these works so long as credit is given. To copy in all other cases or to republish or to post on a server or to redistribute to lists requires specific permission and payment of a fee. Contact Publisher@InformingScience.org to request redistribution permission. multi-national project in European Aerospace engineering.

Dr. Linda Newnes is currently Senior Lecturer in the Innovative Manufacturing Research Centre [IMRC] of the Department of Mechanical Engineering at the University of Bath. From a background in Engineering Design, her current research interests include: Printed Circuits, Engineering Management In- 
formation Systems, Industrial Systems Engineering, Production Engineering, Automation, Engineering Design, Manufacturing Engineering, Computer-Aided Engineering, Quality/Product Control, Production/Operations Management, Expert Systems, Computer Simulation/Modeling, Optimization, Technology Planning/Policy 